\title{
Analysis of the variation of the compressibility index (Cc) of volcanic clays and its application to estimate subsidence in lacustrine areas
}

\author{
D. Carreón-Freyre ${ }^{1}$, M. González-Hernández ${ }^{2}$, D. Martinez-Alfaro ${ }^{3}$, S. Solís-Valdéz $^{1}$, \\ M. Vega-González ${ }^{1}$, M. Cerca ${ }^{1}$, B. Millán-Malo ${ }^{4}$, R. Gutiérrez-Calderón ${ }^{2}$, and F. Centeno-Salas ${ }^{3}$ \\ ${ }^{1}$ Centro de Geociencias de la UNAM Juriquilla. Queretaro, Mexico \\ ${ }^{2}$ Centro de Evaluación de Riesgos Geológicos CERG, Iztapalapa, Mexico City, Mexico \\ ${ }^{3}$ Posgrado en Ciencias de la Tierra, UNAM Juriquilla, Queretaro, Mexico \\ ${ }^{4}$ Centro de Física Aplicada y Tecnología Avanzada, UNAM Juriquilla, Queretaro, Mexico
}

Correspondence to: D. Carreón-Freyre (freyre@geociencias.unam.mx)

Published: 12 November 2015

\begin{abstract}
An analysis of the deformation conditions of lacustrine materials deposited at three sites in the volcanic valley of the Mexico City is presented. Currently geotechnical studies assume that compressibility of granular materials decreases in depth due to the lithostatic load. That means that the deeper the sample the more rigid is supposed to be, this assumption should be demonstrated by a decreased Compression Index (Cc) in depth. Studies indicate that Mexico City clays exhibit brittle behaviour, and have high water content, low shear strength and variable $\mathrm{Cc}$ values. Furthermore, groundwater withdrawal below the city causes a differential decrease in pore pressure, which is related to the physical properties of granular materials (hydraulic conductivity, grain size distribution) and conditions of formation. Our results show that $\mathrm{Cc}$ for fine grain materials (lacustrine) can be vertically variable, particularly when soils and sediments are the product of different volcanic materials. Lateral and vertical variations in the distribution of the fluvio-lacustrine materials, especially in basins with recent volcanic activity, may be assessed by $\mathrm{Cc}$ index variations. These variations can also be related to differential deformation, nucleation and propagation of fractures and need to be considered when modelling land subsidence.
\end{abstract}

\section{Introduction}

Mexico City is the best known example of land subsidence in Mexico (Fig. 1). The city is located within the geological province of the Transmexican Volcanic Belt (Ferrari et al., 2012), over a desiccated lacustrine plain bounded by faults and volcanic edifices. The near-surface lithology in the Mexico basin is highly heterogeneous and includes fluviolacustrine sediments with particle sizes varying from gravel, sand, and silts to clays, with interbedded layers of pyroclastic rocks and lava flows (Carreón-Freyre, 2010, Carreón-Freyre et al., 2011). Analyses of groundwater withdrawal and of the associated land subsidence have been documented systematically in Mexico City since the 1940s (Carrillo, 1947). As a consequence of descending water level, the Basin of Mexico has been divided in several clay bearing fluvio- lacustrine sub-basins, which include Mexico City, TlahuacChalco, Texcoco, Xochimilco, and Zumpango basins.

Although subsidence in Mexico City is thought to be related to high compressibility rates of the clayey sequences when the pore pressures decrease (Mesri et al., 1976), there is a lack of systematic studies to explain the compositional and mechanical behavior variations in clayey sequences and their role on the estimation of vertical deformation. The Compression Index (Cc; Lambe and Whitman, 1969) is obtained from the void ratio vs log of normal effective stress plot in consolidation tests (ASTM, 1994), and was developed for the estimation of settlements for fine-grained deposits. The evaluation of vertical and lateral variations in the Compression Index Cc may facilitate the assessment of the potential of land subsidence in clay-bearing sequences. Several authors (see Haigh et al., 2013; and references therein) found that $\mathrm{Cc}$ 


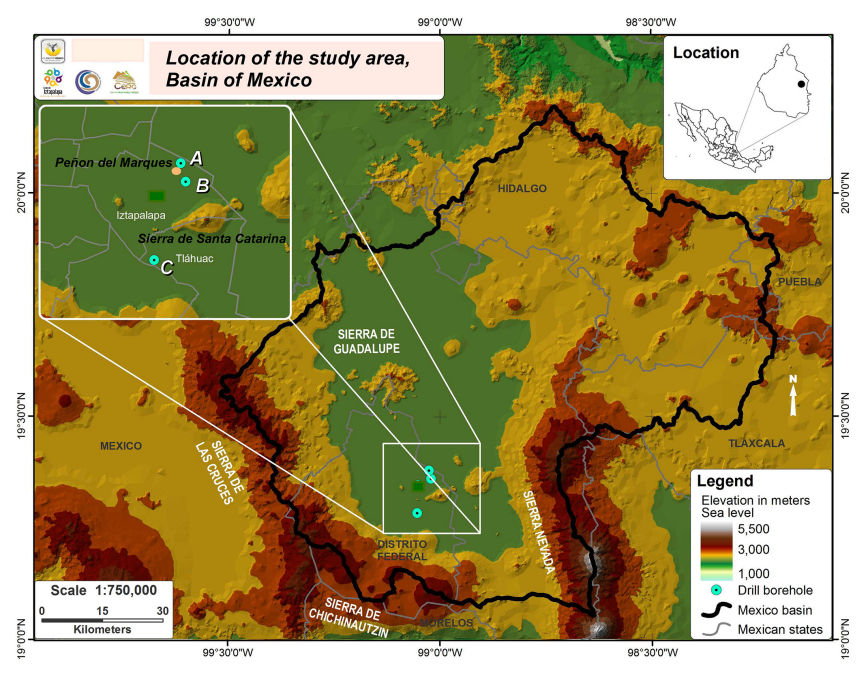

Figure 1. Location of the study areas in the Basin of Mexico (black polygon), Iztapalapa and Tlahuac. The geotechnical borehole locations are shown by blue circles: (A) La Cascada, (B) Lucio Blanco, (C) Tlahuac. Lacustrine planes are shown in green and volcanic structures in yellow and red. Grey lines indicate administrative boundaries.

can be correlated with water content, Atterberg Limits, and void ratio variations $(e)$. The presented analysis of the $\mathrm{Cc}$ was made on silt and clayey deposits because of the strong interdependence of water content and compressibility with mineralogy, mechanical behaviour, and structure.

Three silty and clayey sequences, located in Iztapalapa and Tlahuac localities (Fig. 1), are compared to identify the conditions of formation and evolution that led to their physical and mechanical properties. The systematic characterization of these sequences included compressibility, grain size distribution, mineralogy of clays (analyzed by X-ray diffraction), water content, and other physical parameters.

\section{Lacustrine deposits in the Iztapalapa and Tlahuac-Chalco sub-basins}

The near surface stratigraphy of Iztapalapa and Tlahuac areas comprise fluvial and lacustrine sequences (silt and clay bearing) interbedded with tephra and lava (Zeevaert, 1953). The main volcanic structures are the Sierra de Santa Catarina volcanic complex, that separates the Iztapalapa and Thalhuac sub-basins and, the Peñon del Marques located at the north of the Iztapalapa plain. Weathering and hydrothermal alteration of basaltic rocks and volcanic ashes generate different types of clays (Hillier, 1995; Velde, 1995; Wada, 1987). The influence of mineralogy composition of clays on the mechanical behavior of lacustrine materials in Mexico City has been widely studied (Diaz-Rodriguez et al., 1998; Peralta y Fabi, 1989). The physical characteristics and composition of the lacustrine deposits have been documented from geotechnical and geophysical surveys (Carreón-Freyre and Cerca 2006;
Hernández-Marin et al., 2005; Carreón-Freyre et al., 2003). Clays are metastable materials, their forming processes are sequential and the existence of each type is restricted to specific temperature and time spans. The environmental conditions of a lake are a consequence of its salinity, $\mathrm{pH}$, water depth, temperature, and water residence time (with restricted drainage). These conditions varied dramatically in very short periods because of the intense local volcanic activity (mafic or silicic in composition, effusive and/or pyroclastic rocks) in the sub-basins of the Basin of Mexico and their interaction with the lake deposits. The water level of the former lakes also played an important role to differentiate lacustrine conditions in adjacent sub-basins, such as Iztapalapa and Tlahuac.

A common clay mineral assumed to predominate in the sediments of the Basin of Mexico is montmorillonite, from the smectite family (Diaz Rodriguez, et al., 1998; Peralta y Fabi, 1989), that is characterized by: (1) $2: 1$ crystalline layered structure (2 tetrahedral sheets to 1 octahedral sheet) (Velde, 1995); (2) high values of plasticity and compressibility index (Hernandez-Marin and Carreón-Freyre, 2002); (3) large amounts of water retained in structure (generally more than $100 \%)$; and, (4) high solids density $\left(2.5 \mathrm{~g} \mathrm{~cm}^{-3}\right)$. Smectite formation is favored in lake areas with restricted drainage and low saline-alkaline conditions (Hillier, 1995). In such environments, iron ( $\mathrm{Fe}$ ) oxidizes and accumulates. When the lake level increases, iron reduces and becomes soluble forming green clay sequences (Carreón-Freyre et al., 2006). Mafic minerals (e.g., olivine and pyroxene) from volcanic rocks may form chlorite and talc. Moreover, alteration of pumicite-rich volcanic ashes produces allophane and imogolite, clay minerals of low crystalline order having a gel-like structure, low vertical compressibility, and susceptibility to shear deformation (Wesley, 2001). These materials have a characteristic amorphous spectrum (with no specific clay reflexions) of X-Ray Difraction (XRD) analysis (Carreón-Freyre et al., 2006). If the environmental conditions favor dehydration, these materials become gibbsite, halloysite, and talc (Velde, 1995). Heterogeneity of mineral content (mica, pyroxene, and plagioclase) suggests a close similarity with the volcanic source and less chemical equilibrium. The close relation between mineralogical conditions of the clayey materials, their ability to retain water, and their compressibility has been doumented by Haigh et al. (2013), Robinson (1999) and Warren and Rudolph (1997).

\section{Characterization of the studied sequences}

The three study sites were selected after detailed mapping of the fluvio-lacustrine sediments and volcanic rocks. Geological mapping was complemented with a topographic survey of the sites with evidence of ground surface deformation, where vertical displacements varied from $50 \mathrm{~cm}$ to $3 \mathrm{~m}$. The different sites have approximately the same elevation. Samples 

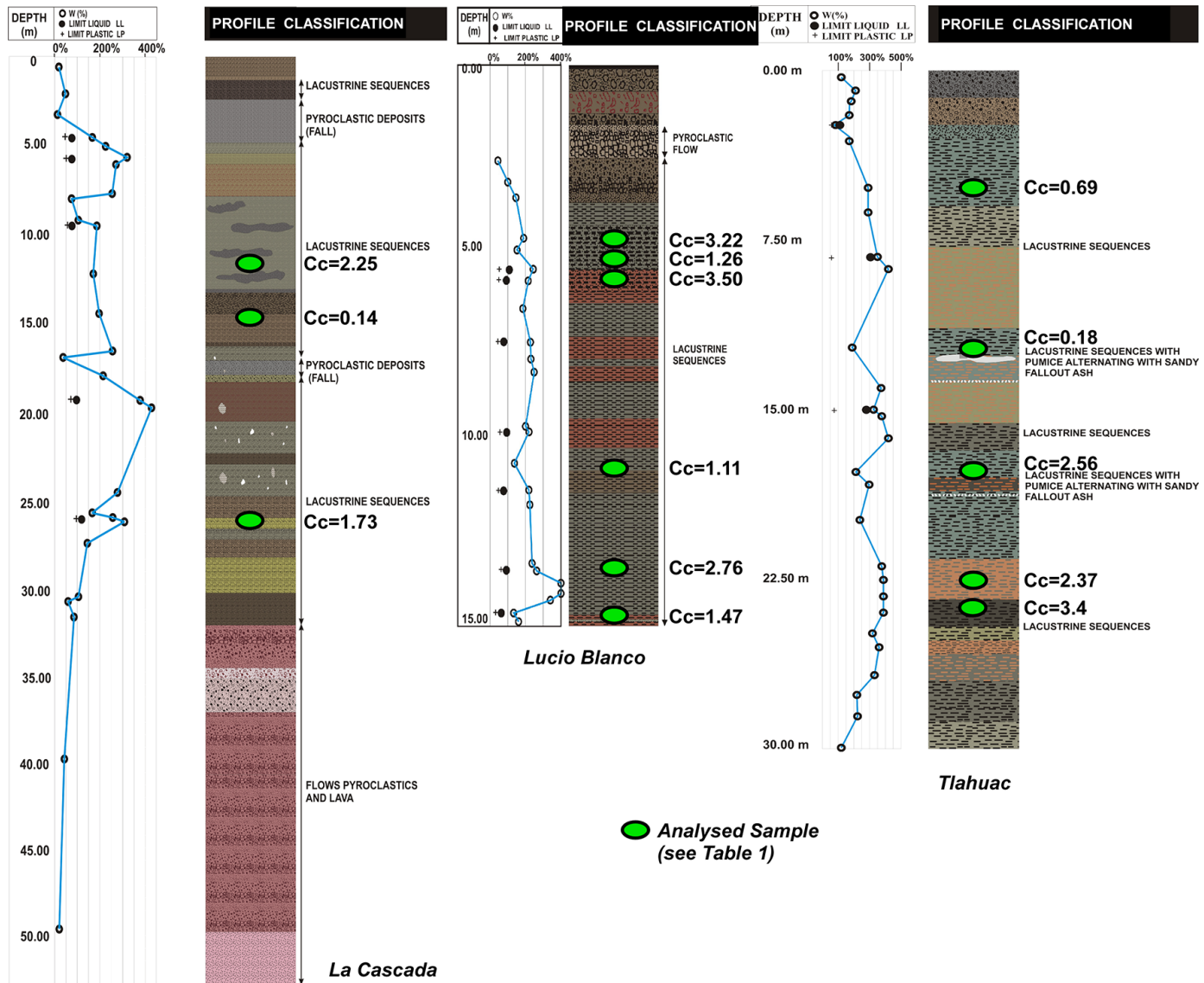

Figure 2. Lithological correlation of three fluvio-lacustrine and volcanic sequences in the Iztapalpa (La Cascada and Lucio Blanco) and Tlahuac sub-basins, obtained from geotechnical boreholes. Green ellipses indicate the location in depth of non-altered samples used for physical and mechanical characterization (see Fig. 1 for location).

were collected through three geotechnical boreholes named La Cascada (50 m depth), Lucio Blanco (15 m depth), and Tlahuac (30 m depth) (Figs. 1 and 2).

\subsection{Physical properties and clay mineralogy}

Physical properties of the collected samples were determined in the Laboratorio de Edafología and the Laboratorio de Mecánica de Geosistemas (LAMG), of the Centro de Geociencias, UNAM. These determinations included: gravimetric water content ( $\mathrm{W}_{\text {grav }} \%$ ), grain-size distribution by sieving and fine-grain distribution using the Bouyoucos densitometer, organic matter content $(\%)$, and solid density $\left(S_{\mathrm{s}}\right)$ by the pycnometer method. Particles with diameters smaller than 2 microns were segregated from samples and dried at room temperature. They were crushed in an agate mortar and sieved with a 200 mesh. Carbonates were removed by washing with buffer solution of sodium acetate-acetic acid (Buhrke et al., 1998). Subsequently the samples were washed with deionized water and mild sonic vibration was applied. Particle dispersion was propitiated by the addition of sodium hexametaphosphate. Samples for XRD analysis were pre- pared according to the standard methodology proposed by Buhrke et al. (1998); and were analyzed at the Laboratorio de Difracción de Rayos X, Centro de Fisica Aplicada y Tecnologia, UNAM. The microstructure of some samples were also analyzed using a Scanning Electron Microscope (SEM) and an Transmission Electron Microscope (TEM) in the Laboratorio de Fluidos Corticales, Centro de Geociencias.

\subsection{Mechanical properties: compressibility}

More than 30 borehole samples were tested by the standard incremental consolidation method in order to determine their compressibility $(\mathrm{Cc})$ and overconsolidation ratio (OCR, overconsolidated having values $>1$ ), but only 14 representative samples are discussed in this work (Table 1 and Figs. 2 and 3). Samples were classified according to the Unified Soil Classification System (USCS). Liquid limit (LL), plastic limit (PL), and plasticity Index (PI) were determined. Each type of soil has a certain water retention capacity and, therefore, its plasticity index may reflect their mineralogical condition. The pneumatic consolidometer used for the compressibility tests (ASTM, 1998) included measurements of 
Table 1. Physical and mechanical characterization of the studied lacustrine sequences. $S_{\mathrm{S}}$, solid density; $W_{\text {grav }}$, gravimetric water content; GSD, Grain Size Distribution: C, Clay, M, Silt, S, Sand; $e_{0}$ and $e_{\mathrm{f}}$, initial and final void ratio, OCR, Overconsolidation Ratio, Cc, Compressibility Index, USCS, Unified Soil Classification System: MH, High Plasticity Silt, SM, Silty Sand.

\begin{tabular}{|c|c|c|c|c|c|c|c|c|c|}
\hline $\begin{array}{l}\text { Depth } \\
\mathrm{m}\end{array}$ & $\begin{array}{r}S_{\mathrm{S}} \\
\mathrm{g} \mathrm{cm}^{-3}\end{array}$ & $\begin{array}{r}W_{\text {grav }} \\
\%\end{array}$ & $\begin{array}{r}\text { LL-PI/IP } \\
\%\end{array}$ & $\begin{array}{r}\text { GSD } \\
\mathrm{C} / \mathrm{M} / \mathrm{S}\end{array}$ & $e_{0}-e_{\mathrm{f}}$ & $\Delta e$ & OCR & $\mathrm{Cc}$ & USCS \\
\hline \multicolumn{10}{|c|}{ Tláhuac } \\
\hline 6.0 & 2.20 & 106 & $74-59 / 15$ & $14 / 60 / 26$ & $2.5-2.1$ & 0.4 & 13 & 0.69 & $\mathrm{MH}$ \\
\hline 12.15 & 2.21 & 187 & $76-57 / 19$ & $19 / 43 / 38$ & $3.5-3.3$ & 0.2 & 2.8 & 0.18 & $\mathrm{MH}$ \\
\hline 17.05 & 2.27 & 228 & $123-90 / 33$ & $11 / 32 / 57$ & $5.3-2.4$ & 2.9 & 1 & 2.56 & $\mathrm{MH}$ \\
\hline 22.6 & 2.23 & 260 & $95-67 / 28$ & $15 / 62 / 23$ & $5.2-2.5$ & 2.7 & 1 & 3.13 & MH \\
\hline 22.9 & 2.05 & 260 & $136-90 / 46$ & $15 / 62 / 23$ & $7.6-3.2$ & 4.4 & 1 & 3.40 & MH \\
\hline \multicolumn{10}{|c|}{ La Cascada } \\
\hline 12.65 & 2.43 & 203 & $87-61 / 26$ & $16 / 34 / 50$ & $4.7-2.2$ & 2.5 & 1.8 & 2.25 & MH \\
\hline 14.65 & 2.53 & 45 & - & $7 / 15 / 78$ & $0.8-0.7$ & 0.1 & 3.7 & 0.14 & SM \\
\hline 26.84 & 2.26 & 130 & $103-74 / 29$ & $16 / 38 / 46$ & $3.0-1.4$ & 1.6 & 10 & 1.73 & $\mathrm{MH}$ \\
\hline \multicolumn{10}{|c|}{ L. Blanco } \\
\hline 4.7 & 2.39 & 190 & - & $12 / 29 / 59$ & $5.1-2.8$ & 2.3 & 12.5 & 3.22 & SM \\
\hline 5.6 & 2.26 & 234 & $103-74 / 29$ & $24 / 29 / 47$ & $0.8-0.0$ & 0.8 & 5.5 & 1.26 & MH \\
\hline 5.85 & 2.21 & 222 & $96-72 / 24$ & $46 / 31 / 23$ & $4.9-1.8$ & 3.1 & 6.5 & 3.5 & MH \\
\hline 11.5 & 2.23 & 213 & $75-59 / 16$ & $19 / 36 / 45$ & $3.2-1.8$ & 1.4 & 20.5 & 1.1 & $\mathrm{MH}$ \\
\hline 14.1 & 2.23 & 302 & $101-67 / 34$ & $18 / 37 / 45$ & $5.9-2.2$ & 3.7 & 1.4 & 2.76 & $\mathrm{MH}$ \\
\hline 14.8 & 2.36 & 120 & $59-47 / 12$ & $6 / 41 / 53$ & $2.9-1.7$ & 1.2 & 3.6 & 1.47 & SM \\
\hline
\end{tabular}

variations of axial pressure, back pressure, pore pressure and displacement with electronic sensors (Hernandez-Marin and Carreón-Freyre, 2002). The description of its operation and data acquisition software is detailed in Flores et al. (2010). Compression Index $(\mathrm{Cc})$ and Overconsolidation Ratio (OCR) were obtained from graphs of void ratio vs log effective stress.

Results obtained for representative samples (14 out of more than 30) of the three studied sequences are presented in Table 1. Mostly, sediments are high plasticity silts $(\mathrm{MH})$ with some intercalations of uniform sand and gravel deposits of black colour and ash layers (sandy silts) that correspond to pyroclastic deposits. Water content varies from 0 to $100 \%$ for pyroclastic deposits and from 200 to $300 \%$ for lacustrine deposits (Fig. 2). Variations of colour from red to olive green indicate the oxidation or reduction of iron $(\mathrm{Fe})$ present in clays. Likely, local variations of $\mathrm{pH}$, temperature, and salinity produced different clayey materials within the same depositional environment. In the La Cascada samples green colours of the clayey sediments denote a reduction condition indicating a water cover. The Lucio Blanco site is located in a channel that connected with the Texcoco sub-basin from the north within the lacustrine area of Iztapalapa (Fig. 1). Variations of the water level in the channel might have varied conditions from dry to humid, and the presence of Fe and magnesium $(\mathrm{Mg})$ from basaltic rocks propitiated the crystallization of smectite clays, such as montmorillonite. In the Tlahuac site, the sequence is composed mainly by pumice and ash (silicic py- roclastic deposits) that rapidly generated fine grain materials, rich in silica $\left(\mathrm{SiO}_{2}\right)$, and with a low level of crystallization. The initial void ratio $\left(e_{0}\right)$ for each layer indicates the potential compressibility and is directly related to the grain size and mineralogy.

Three samples from different lacustrine layers at 12, 14, and $27 \mathrm{~m}$ depth in La Cascada borehole are overconsolidated. The highest $\mathrm{Cc}$ value and the higher water content correspond to the $12 \mathrm{~m}$ sample and the plasticity index (IP) is similar to that of $27 \mathrm{~m}$ sample which has the lower Cc value (Table 1, Fig. 3b). The sequence is interpreted to be formed by clayey well crystallized lacustrine sediments.

In the Lucio Blanco borehole, six samples were tested from 4.7, 5.6, 5.85, 11.5, 14.1, and $14.8 \mathrm{~m}$ depth. The highest $\mathrm{Cc}$ value corresponds to the 5.85 depth but does not present the highest water content or IP. The lowest Cc value corresponds to a sandy material that is a pyroclastic flow deposit (Fig. 3c and d). Pyroclastic deposits in general behave as non-cohesive potentially collapsible material. The sequence was interpreted as a wetland area within a lake channel, the red colour (oxidation) of the lacustrine deposits indicated large variations of water level.

In the Tláhuac borehole, five samples were tested from 6, $12,17,22.6$, and $22.9 \mathrm{~m}$ depth. The highest Cc value corresponds to the deepest layer and the two lowest to the shallower layers. Also in this case the most compressible layer does not present the highest water content, neither the highest IP (Fig. 3a). The sequences is interpreted to be mainly 

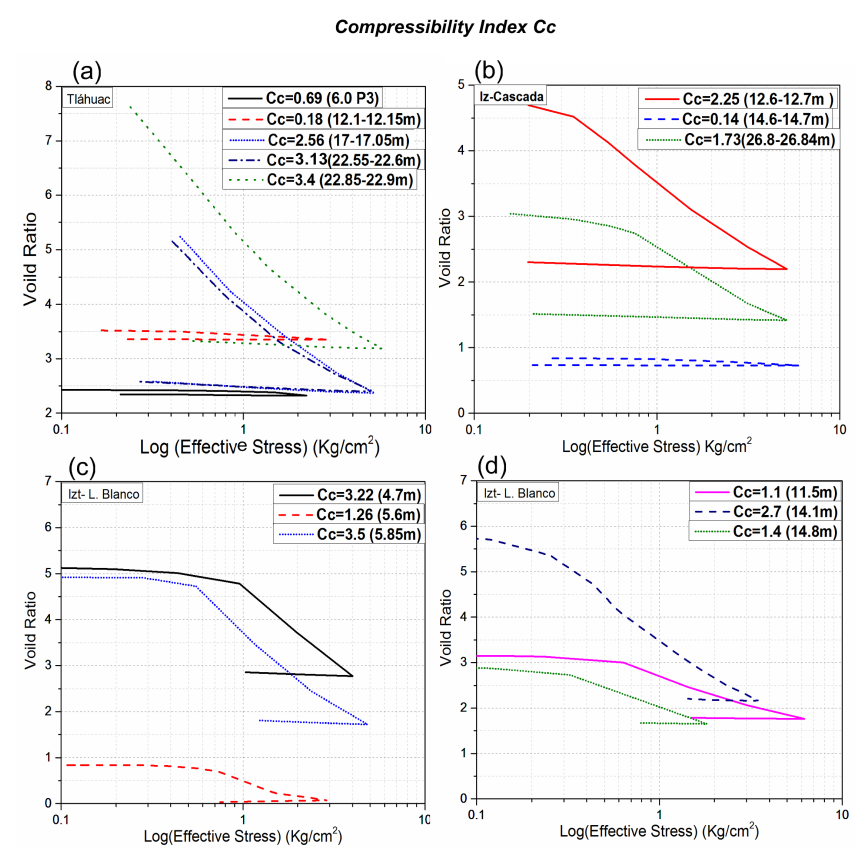

Figure 3. Compressibility plots of samples from the three borehole samples. (a) Five normally consolidated samples from 6 to $22.9 \mathrm{~m}$ depth in the Tlahuac site, only the material in the surface is over consolidated and have the smaller Cc value and the deeper samples have the higher Cc values; (b) three over consolidated samples from 12.6 to $26.8 \mathrm{~m}$ depth in La Cascada site, the lowest Cc value is placed at $14 \mathrm{~m}$ depth and the highest at $12 \mathrm{~m}$ depth; (c and d) six over consolidated samples from 4.7 to $14.8 \mathrm{~m}$ depth in the Lucio Blanco site, the lower Cc value corresponds to a $11.5 \mathrm{~m}$ depth sample and the higher at $5.85 \mathrm{~m}$ depth. Note also high variations in $\mathrm{Cc}$ for the same depth (e.g. at $12 \mathrm{~m}$ depth: $0.18,2.25$, and 1.1) for the different sequences.

formed by amorphous materials, formed by the alteration of ashes, that may explain the apparently contradictory values.

\subsection{Mineralogy}

For better understanding of the Cc variations we carried out XRD analysis in order to identify mineralogy; SEM and TEM imaging to characterize structure. Figure 4 shows some of the results for the Lucio Blanco and Tlahuac sites. The XRD records of the sample from $14 \mathrm{~m}$ depth in the Lucio Blanco site, show heterogeneous mineralogical composition of the entire sample: mica, illite, anorthite, silica, talc, and possibly nontronite. The clay fraction sample (after washing salt) indicates the presence of montmorillonite and cristobalite (silica) (Fig. 4a). Anorthite, a calcium plagioclase, and mica are minerals formed during volcanic eruptions that have not been completely altered. Cristobalite may have a volcanic origin or be part of the diatomaceous frustule (e.g., Marsal and Mazari, 1959). The montmorillonite suggests saturated conditions during its formation. The presence of talc indi- cates alteration of the basic volcanic minerals at high salinity and temperatures below $100^{\circ} \mathrm{C}$ (Velde, 1995).

The XRD record for the Tlahuac samples indicates the presence of vermiculite which also is related to the alteration of volcanic minerals (an example from $22 \mathrm{~m}$ depth is presented in Fig. 4a). Amorphous material and low-crystallized materials cannot be identified by XRD but SEM and TEM can identify such materials. The SEM image presented in Fig. 4b corresponds to a silty clay from $6 \mathrm{~m}$ depth (Fig. 4b1), and to a low crystallized material from $22 \mathrm{~m}$ depth (Fig. 4b1 and b2). The Fig. $4 \mathrm{~b} 3$ was obtained using an TEM and shows the lack of structure. This material is similar to allophane and is a product of the alteration of acid volcanic ashes.

\section{Discussion}

The results of the physical characterization presented in this paper indicate that the conditions of formation and the evolution of lacustrine sequences control mechanical behaviour, and ultimately differential subsidence in the Basin of Mexico, and particularly in Mexico City. The silty-clay fraction has a highly heterogeneous composition including partially altered volcanic ash, illite, smectite, and allophane.

These materials are usually assumed to be highly compressible and with low resistance to shear. However, complex consolidation of these materials is also influenced by the displacement of free water, adsorbed water and/or intermolecular water, which holding force is dependent on the mineralogical characteristics of the solid phase. In such lacustrine materials having a metastable structure and mineralogy the mechanical behavior cannot be represented only by one plasticity or compressibility index. Lacustrine clay heterogeneity due to changes in depositional environment should be considered for a proper assessment of the compressibility index variations. This parameter is the most important because it is widely used for the estimation of land subsidence and, hence of the fracturing susceptibility of sediments.

A common assumption is that $\mathrm{Cc}$ decreases with depth due to lithostatic load; however, the analysis of the data presented in this work suggest a different mechanical behaviour for the lacustrine sediments. The mixture of silt and sand composed of silica, talc, and plagioclase with smectite clays (montmorillonite) presents variable consolidation conditions. Sandy lenses are less compressible, although the silt and clay content is higher. For the case of Tlahuac, it should be noted that the sand corresponds to pyroclastic materials composed of pumice that may degrade and change structure in hundreds or tens of years, and this explains the presence of low crystallized materials in the whole sequence. These materials show a lower plasticity than the smectites, higher contraction limits and a brittle behavior. The lateral and vertical compressibility variations are one of the causes of the substantial differential deformation observed in the study area. The high water 


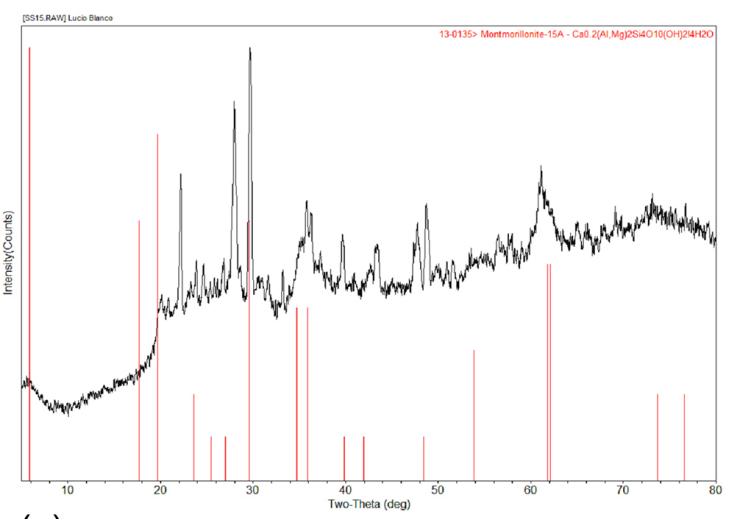

(a) Lucio Blanco $14 \mathrm{~m}$ depth, montmorillonite

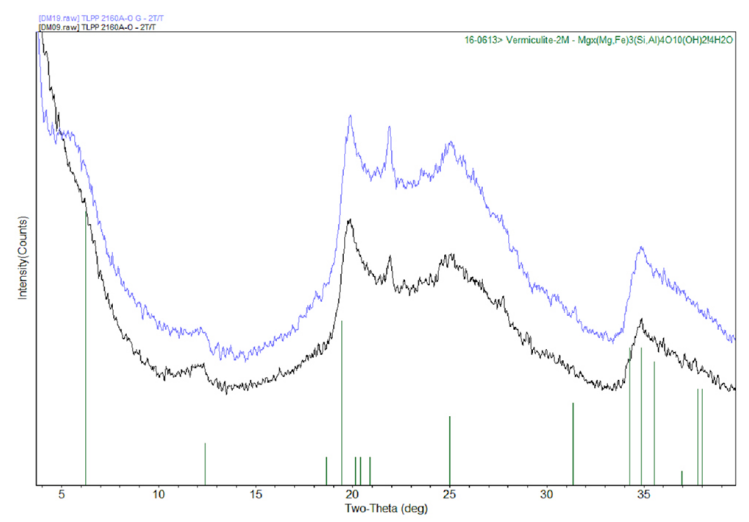

Tlahuac 22 m depth, vermiculite, allophane.

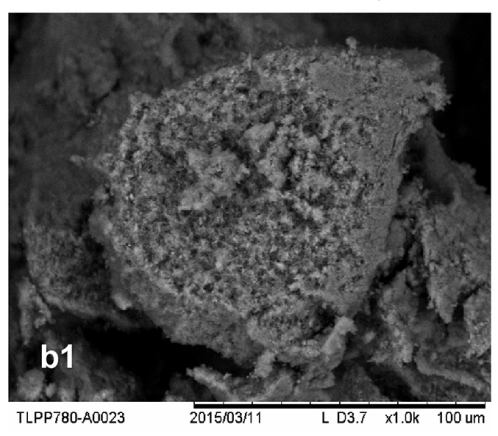

(b)

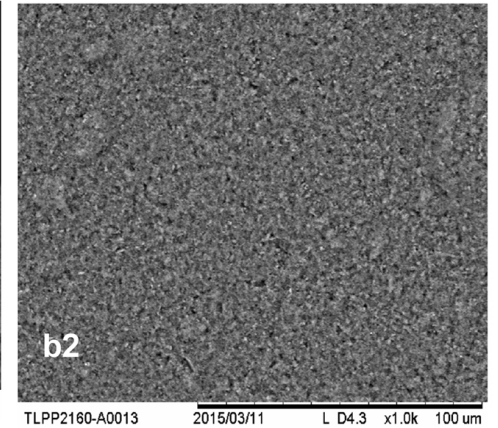
Tlahuac, SEM and TEM analysis

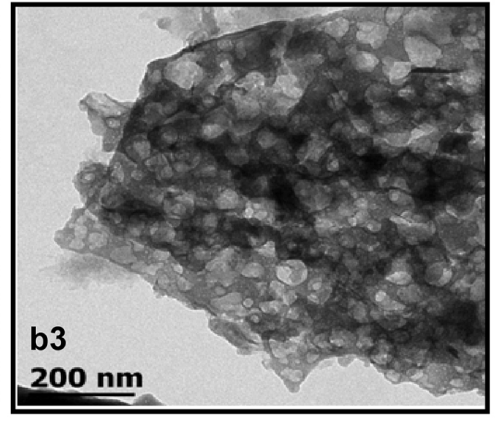

b3

Figure 4. Characterization of the mineralogy and structure of clayey materials. (a) XRD analysis of clays from the Lucio Blanco site (14 m depth) showing the montmorillonite signature and from Tlahuac $(22 \mathrm{~m}$ depth) showing the signature of vermiculite and low crystallized material; (b) SEM images from Tláhuac deposits: (b1), is a silty material at $6 \mathrm{~m}$ depth; (b2); is a low crystallized material at $22 \mathrm{~m}$ depth and, the (b3) image, taken using an TEM, shows the lack of structure in material similar to allophane.

content values suggest that these materials have low shear strength and fracture easily. Once fractured, the space created is filled with material coming from the surface creating a tensional state of stress that propitiates the propagation of fracturing to the surface.

Furthermore, the studied silt-clay sequences are commonly interbedded with fluvial and pyroclastic granular materials and/or volcanic rocks, which increase the mechanical heterogeneity of sequences and favours differential deformation. Fracturing of the subsurface in the Basin of Mexico, (e.g. Iztapalapa and Tlahuac) might be provoked by several factors, such as groundwater withdrawal and regional faulting; nevertheless, the gradual deformation related to differential consolidation between the different types of fluviolacustrine materials in volcanic areas also play an important role and should be better studied.

Acknowledgements. The authors acknowledge the work of characterization of samples in the laboratory of Mr. Ricardo Carrisoza, laboratory technician in the Laboratorio de Mecánica de Geosistemas (LAMG) at the Centro de Geociencias. The field support of Mr. Cesar Tovar CERG-Iztapalapa is also appreciated. The authors also thank support from the UNAM DGAPA Project PAPIIT No. 114174.

\section{References}

American Society for Testing Materials (ASTM): D2435-96 Standard method for one-dimensional consolidation properties of soils, ASTM Standards, USA, 5 pp., 1998.

Buhrke, V. E., Jenkis, R., and Smith, D. K.: A practical guide for the Preparation of specimens for X-ray Fluorescene and X-Ray diffraction Analysis, Wiley-VCH, New York, 333 pp., ISBN: 0471-19458-1, 1998.

Carreón-Freyre, D.: Land subsidence processes and associated ground fracturing in Central Mexico, in: Land Subsidence, Associated Hazards and the Role of Natural Resources Development (Proceedings of EISOLS 2010, Querétaro, México), edited by: Carreón-Freyre, D., Cerca, M., and Galloway, D. L., Red Book Series Publication 339, IAHS Press, CEH Wallingford, UK, ISBN: 978-1-907161-12-4, ISSN: 0144-7815, 149-157, 2010.

Carreón-Freyre, D. and Cerca, M.: Delineating the near-surface geometry of the fracture system affecting the valley of Queretaro, Mexico: Correlation of GPR signatures and physical properties of sediments, Near Surface Geophysics, EAGE (European Assoc. of Geoscientists and Engineers), 4, 49-55, 2006.

Carreón-Freyre, D. C., Cerca, M., and Hernández-Marín, M.: Correlation of near-surface stratigraphy and physical properties of clayey sediments from Chalco Basin, Mexico, using Ground Penetrating Radar, J. Appl. Geophys., 53, 121-136, 2003. 
Carreón-Freyre, D. C., Hidalgo-Moreno, C., and Hernández-Marín, M.: Mecanismos de fracturamiento de depósitos arcillosos en zonas urbanas. Caso de deformación diferencial en Chalco, Estado de México, Boletín de la Sociedad Geológica Mexicana, Número Especial de Geología Urbana, Tomo LVII, 2, 237-250, 2006.

Carreón-Freyre, D., González-Hernández, M., Cerca M., and Gutiérrez-Calderón, R. I.: Caracterización geomecánica de los suelos de Iztapalapa, México, para evaluar el fracturamiento causado por deformación diferencial, Proceedings of the 14th PanAmerican Conference on Soil Mechanics and Geotechnical Engineering, 2-6 October 2011, Toronto, Canada, 2011.

Carrillo, N.: Influence of artesial wells in the sinking of Mexico City, en Volumen Nabor Carrillo "El hundimiento de la Ciudad de México y el Proyecto Texcoco", Comisión Impulsora y Coordinadora de la Investigación Científica Anuario, 47, 7-14, 1947.

Díaz-Rodríguez, A., Lozano-Santacruz, R., Dávila-Alcocer, V. M., Vallejo, E., and Girón, P.: Physical, chemical, and mineralogical properties of México City sediments: a geotechnical perspective, Can. Geotech. J., 35, 600-610, 1998.

Ferrari, L., Orozco-Esquivel, T., Manea, V., and Marina, M.: The dynamic history of the Trans-Mexican Volcanic Belt and the Mexico subduction zone, Tectonophysics, 522-523, 122-149, doi:10.1016/j.tecto.2011.09.018, 2012.

Flores, C. O., Gómez, R. E., Hernández, M. S., and Carreón Freyre, D.: Automatización de un consolidómetro neumático, Memorias de la XXV Reunión Nacional de Mecánica de Suelos e Ingeniería Geotécnica, Mexico, ISBN: 978-968-5350-23-5, 8-16, 2010.

Haigh, S. K., Vardanega, P. J., and Bolton, D.: The plastic limit of clays, Géotechnique, 63, 435-440, doi:10.1680/geot.11.P.123, 2013.

Hernández-Marín, M., Carreón-Freyre., D., and Cerca Martínez, M.: Mechanical and physical properties of the montmorillonitic and allophanic clays in the near-surface sediments of Chalco Valley, Mexico: Analysis of contributing factors to land subsidence, Proceedings of the 7th International Symposium on Land Subsidence SISOLS 2005, 23-28 October 2005, Shanghai, China, ISBN: 7-5323-8209-5, Vol. I, 276-285, 2005.
Hillier, S.: Erosion, sedimentation and sedimentary origin of clays, in: Composition and mineralogy of Clay Minerals, edited by: Velde, B., Springer-Verlag, Berlin, Heidelberg, New York, 162214, ISBN: 3-540-58012-3, 1995.

Lambe, W. T. and Whitman, R. V.: Soil Mechanics, John Wiley and Sons Inc., NY, 553 pp., 1969.

Marsal, R. J. and Mazari, M.: El subsuelo de la Ciudad de México, Instituto de Ingeniería, U.N.A.M. I, II, Mexico, 505 pp., 1959.

Mesri, G., Rokhse, A., and Bonor, B. F.: Composition and compressibility of typical samples of Mexico City clay, Geotechnique, 25, 527-554, 1976.

Peralta y Fabi, R.: Sobre el origen de algunas propiedades mecánicas de la formación arcillosa superior del Valle de México, Simposio sobre Tópicos Geológicos de la Cuenca del Valle de México, Mexico, 282 pp., 1989.

Robinson, R. G.: Consolidation analysis with pore pressure measurements, Géotechnique, 49, 127-132, 1999.

Velde, B.: Origin and Mineralogy of Clays, Clays and the environment, Springer-Verlag, Berlin, Heidelberg, New York, 334 pp., ISBN: 3-540-58012-3, 1995.

Wada, K.: Minerals formed and mineral formation from volcanic ash by weathering, Chem. Geol., 60, 17-28, 1987.

Warren, C. J. and Rudolph, D. L.: Clay minerals in basin of Mexico lacustrine sediments and their influence on ion mobility in groundwater, J. Contam. Hydrol., 27, 177-198, 1997.

Wesley, L. D.: Consolidation behaviour of allophane clays, Géotechnique, 51, 901-904, 2001.

Zeevaert, L.: Estratigrafía y problemas de ingeniería en los depósitos de arcilla lacustre de la Ciudad de México, Memoria del Congreso Científico Mexicano, 5, 58-70, 1953. 